\title{
A Starch-Based Biodegradable Polyethylene for Municipal Solid Waste Mitigation
}

\author{
Adedoyin Raheem, Bolaji Aremo, Mosobalaje Oyebamiji Adeoye \\ Department of Materials Science and Engineering, Obafemi Awolowo University, Ile-Ife, Nigeria \\ Email: raheemdoyin@yahoo.co.uk, bolaji_aremo@yahoo.com, madeoye@yahoo.com
}

How to cite this paper: Raheem, A., Aremo, B. and Adeoye, M.O. (2017) A StarchBased Biodegradable Polyethylene for Municipal Solid Waste Mitigation. Materials Sciences and Applications, 8, 26-36. http://dx.doi.org/10.4236/msa.2017.81003

Received: December 3, 2016

Accepted: January 2, 2017

Published: January 5, 2017

Copyright $\odot 2017$ by authors and Scientific Research Publishing Inc. This work is licensed under the Creative Commons Attribution International License (CC BY 4.0).

http://creativecommons.org/licenses/by/4.0/

\begin{abstract}
This work reports a method for reducing the longevity of the polymer content of Municipal Solid Wastes (MSW) in the environment. In this approach biodegradability was imparted on polyethylene, a popular, low-cost commodity polymer, using starch additives. Corn starch and cassava starch in varying proportions were compounded with suitably prepared polyethylene powder and compression-moulded in steel dies. Alongside tensile test, biodegradability tests were carried out by burying samples for 28 days in two different soil types with different $\mathrm{pH}$, fungi and bacteria load. Cassava starch additions were found to be better at imparting biodegradability. Also, alkaline soil types with higher bacteria load seemed a more favourable environment for accomplishing biodegradation in the starch-polyethylene composites.
\end{abstract}

\section{Keywords}

Municipal Solid Waste, Polyethylene, Biodegradation, Polymers

\section{Introduction}

One of the natural consequences of today's industrialised world and improved living standard is the rising tide municipal solid wastes (MSW). MSW include wastes such as durable goods (tires, furniture); nondurable goods (newspapers, plastic plates/cups); containers and packaging, (milk cartons, plastic wrap) and other wastes, such as yard waste and food [1]. The wastes emanate from agricultural, industrial, residential, institutional, municipal, commercial, mining, recreational and other human activities [2]. If unchecked, these wastes have the capability of reversing the very gains of industrialisation and impairing on the quality of life of the citizenry. Indeed, social and environmental ills are directly attributable to ineffective MSW disposal. A study by Sam [3] for instance established the links between urban flooding problems and ineffective MSW man- 
agement practices, while improper disposal of waste contribute to disease epidemics (such as cholera dysentery diarrhoea) and land degradation [4].

Composition of MSW varies widely from developed to third world societies. Domestic wastes are those that are collected from dwelling places, such as organic matter resulting from preparation and consummation of food, rags, nylon and ashes which are the remains after various cooking and heating processes [5]. A common trend nowadays however is the increasing proportion of its polymer content. Staley and Barlaz [6] put the proportion of plastics component of MSW at about $10.6 \% \pm 3.0 \%$ for selected municipalities in the United States. In Abuja, Nigeria data available for the year 2000 put the proportion of plastics in MSW at $4.8 \%$ [7]. This situation is due to partly the popularity of polymers the world over for products ranging from drinking cups and disposable wares, to packaging materials and automobile parts. It is also due to the tendency of polymers to accumulate in the environment for long periods due to their relative inertness to biological agents. This situation may get even worse as the ease of processing, low-cost and readily available feedstock will ensure that plastics continue to find newer areas of application.

An effective approach at mitigating MSW would involve a measure targeted at removing the burgeoning polymer content in it. Common methods of disposal of MSW such as composting and incineration are sadly not the proverbial "silver bullet" for MSW with significant polymeric material content. Composting is the most widely practised method of MSW disposal in Nigeria, with spontaneous compost heaps dotting the landscape. Composting relies on biological agents (e.g. bacteria, fungi) and ambient environmental conditions of temperature and moisture to breakdown MSW into harmless biomass. Polymers being famously resistant to biodegradation remain un-reduced in the compost, only to get carried away by wind, animals or scavengers, ultimately ending-up in undesirable places. Incineration, on the other hand, particularly the open-air type, has associated health risks posed by the emission of toxic materials from incinerators [8].

The problem of what to do with the polymer component of MSW is being tackled the world over with the development of many intuitive solutions. Solution methods popular in more developed climes such as recycling are sadly slow in catching up in less developed societies. In the US for instance, 33.2\% of MSW produced in 2007 were recycled or composted [9]. Also, the development of biodegradable polymers has proved popular in developed countries. As such, the world-wide consumption of biodegradable polymers has increased from 14 million $\mathrm{kg}$ in 1996 to an estimated 68 million $\mathrm{kg}$ in 2001 [10]. However, relative higher costs and processing equipment requirements of many of these biodegradable polymers forestall their successful in-roads into low-resource environments like Nigeria. Bio-degradable plastics with properties similar to conventional plastics can be synthesized from starch. However, large scale production in industry is very much costly so it has not been used extensively [11]. Economic concerns must be addressed objectively as biopolymer materials are developed [12]. 
The aim of this work was to develop an easily deployable, low-cost biodegradable polymer based on polyethylene, a cheap and widely used commodity polymer and starch, a by-product of agricultural processing. This solution approach should mitigate the deleterious effect of polymers on the environment through the use of a composite capable of breakdown by normally attainable composting conditions.

\section{Experimental Procedure}

\subsection{Materials for This Work}

1) Polyethylene (PE): This is a low-cost and commercially available polymer popular with polymer processors in Nigeria. The PE used for this work was the low density polyethylene.

2) Corn Starch (CNS): This is starch obtainable from the maize grain, commonly known as corn. It is also grown from the endosperm, or white heart, of the corn kernel. It has a distinctive appearance and feel when mixed raw with water or milk, giving easily to gentle pressure but resisting sudden pressure. The composition of CNS varies depending upon the feedstock, but it may be considered to be approximately $25 \%$ amylase and amylopectin [13].

3) Cassava Starch (CSS): A typical composition of starch is moisture (70\%), starch $(24 \%)$, fibre (2\%), protein (1\%) and other substances including mineral (3\%) [14]. Among the starchy staples, cassava gives a carbohydrate production which is about $40 \%$ higher than rice and $25 \%$ more than maize, with the result that cassava is the cheapest source of calories for both human nutrition and animal feeding [15].

\subsection{Preliminary Processing of Materials}

The starting materials were subjected to preliminary processing outlined as follows.

1) PE: The PE, from injection-moulded products, was cut into pieces small enough to handle, and pulverised into fine powder using the abrasive disc of a bench-top electric grinding machine. The PE was ground into fine powder and classified to between $50-250 \mu \mathrm{m}$ using the $250 \mu \mathrm{m}$ and $50 \mu \mathrm{m}$ wire mesh of a sieve-shaker machine. This was necessary to enable subsequent dry blending with additives of comparable sizes.

2) CNS and CSS: Both the CNS and CSS were prepared in the same manner. These two starch varieties were initially extracted in the wet form and sun dried. About $500 \mathrm{~g}$ mass was later dried in an electric oven at $80^{\circ} \mathrm{C}$ for $4 \mathrm{hrs}$ to significantly remove retained moisture. After this oven drying, the powders were noticeably dry to the touch. It was then ground to powdered form. The drying step was necessary to facilitate dry blending of the starch powder; damp powders do not blend well and rather tend to form clumps.

Three different sets of samples were prepared. The first set, designated as Sample A, was a mixture of varying percentage proportion of CNS and PE. The second set, designated as Sample B, was a mixture of varying percentage propor- 
tion of CSS and PE. The volume fraction of starch powder in both sample sets was varied between $5 \%$ and $20 \%$.

The third set, designated as Sample C was made up of $100 \%$ polyethylene and served as the control sample. The percent composition of the various samples sets is summarised in Table 1 .

\subsection{Production of Tensile Test Specimens}

A flow diagram illustrating the fabrication process is presented in Figure 1. Specimens from each of the sample sets were compression moulded to ASTM D638 46T tensile test pieces at low pressures in a steel die. The specimens were compounded to such volume that was sufficient to fill the die cavity. For all the specimens an overall equivalent mass of $5 \mathrm{~g}$ was prepared for each composition set. Thus, for a specimen from composition set A1, a $5 \%$ of $5 \mathrm{~g}$ (i.e. $0.25 \mathrm{~g}$ starch) was mixed with $4.75 \mathrm{~g}$ PE. Similar procedure was used to determine the compositional weight of constituents for the other specimens. PE and the starch additives were compounded by dry blending using the dry cup of a domestic kitchen blender.

Each prepared mass powdered samples were poured into the die and heated on an electric hot-plate to near melting point. The die was closed by compressing the molten compound with the male half of the die, the entire assemble was then cooled with a cold water spray.

Table 1. Formulations of different PE-starch samples.

\begin{tabular}{ccccc}
\hline Formulations & & PE (\%) & CNS (\%) & CSS (\%) \\
\hline \multirow{2}{*}{ Sample A } & A1 & 95 & 5 & - \\
& A2 & 90 & 10 & - \\
& A3 & 85 & 15 & - \\
& A4 & 80 & 20 & 5 \\
Sample B & B1 & 95 & - & 10 \\
& B2 & 90 & - & 15 \\
\hline Sample C (control) & B3 & 85 & - & 20 \\
\hline
\end{tabular}

\begin{tabular}{|l} 
Polymer \\
Pellets
\end{tabular}$\quad \begin{aligned} & \begin{array}{l}\text { Forming of pellets } \\
\text { into simple flat } \\
\text { profiles }\end{array} \\
& \text { polymer to powder }\end{aligned}$

Blending of polymer powder with dry starch powder in a rotary mixer

Figure 1. A flow diagram illustrating the fabrication process. 


\subsection{Materials Testing}

\subsubsection{Tensile Test}

Tensile test of the compression-moulded specimens was done using Instron Electromechanical Testing System, Model 3369. The tensile test was carried out to determine the effect of the various starch additions on the resulting tensile strength of the composites.

\subsubsection{Biodegradability Test}

Biodegradability test was done by burying batches of samples from each composition set in two different soil types for 28 days. These soil types were designated as soil type 1 and soil type 2 . Close-up photographs of the surfaces of each test sample were taken to provide a visual record of the surface structure of the material prior to burying. The photographs of the samples were also taken at the end of the twenty eight days period.

\section{Results and Discussions}

\subsection{Tensile Test}

The results of tensile tests carried out on the two sample sets and the control are presented in Table 2. From Table 2, the control sample of 100\% PE had a tensile strength of $5.23 \mathrm{~N} \cdot \mathrm{mm}^{-2}$, however, right from $5 \%$ starch; a sharp decline in tensile strength was evident on both sample sets. A plot of ultimate tensile strength vs. starch percent is depicted in Figure 1 for sample sets A and B. From Figure 2 , it was observed that the tensile strength of the composite decreased as the proportion of both CSN and CSS was increased.

The mixtures of the starch and PE may be classed as particulate reinforced composites with a PE matrix. This composite class characteristically does not achieve high strengths like dispersion harden composites. They are aimed mainly at imparting unique properties on a matrix rather than improving

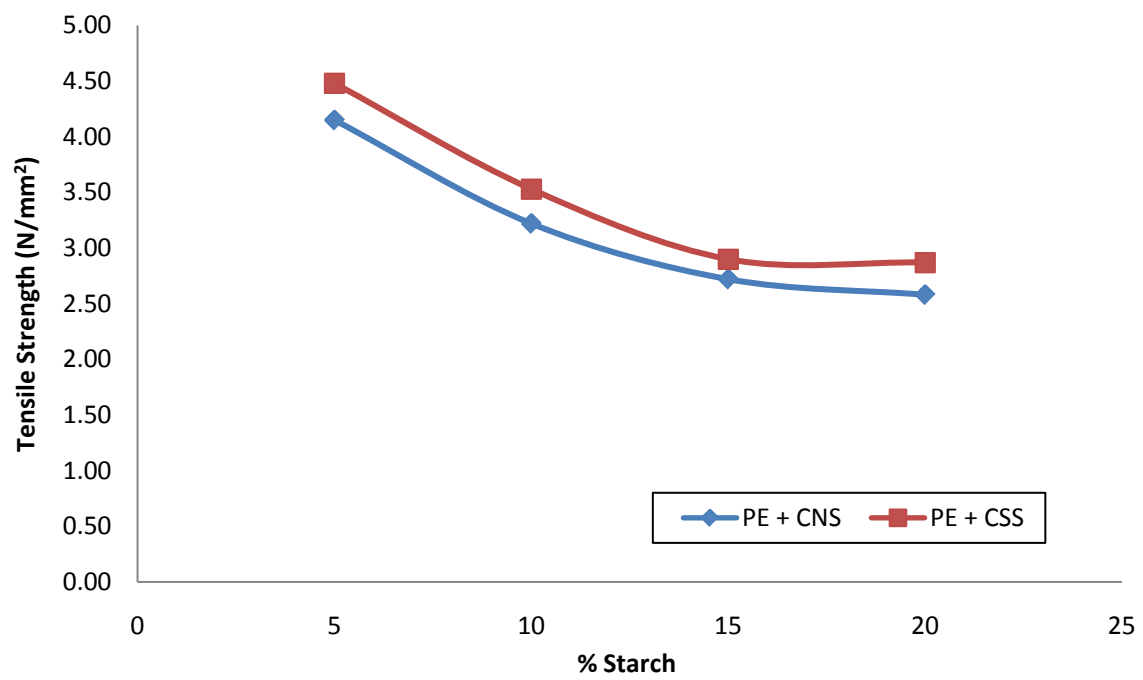

Figure 2. Plot of tensile strength values vs. percent starch for sets $\mathrm{A}(\mathrm{PE}+\mathrm{CNS})$ and $\mathrm{B}$ $(\mathrm{PE}+\mathrm{CSS})$. 
Table 2. Results of tensile test.

\begin{tabular}{|c|c|c|}
\hline \multicolumn{2}{|c|}{ Formulations } & Ultimate tensile strength $\left(\mathrm{N} \cdot \mathrm{mm}^{-2}\right)$ \\
\hline \multirow{4}{*}{ Set A } & $\mathrm{A} 1$ & 4.15 \\
\hline & A2 & 3.22 \\
\hline & $\mathrm{A} 3$ & 2.72 \\
\hline & A4 & 2.58 \\
\hline \multirow{4}{*}{ Set B } & $\mathrm{B} 1$ & 4.48 \\
\hline & $\mathrm{B} 2$ & 3.53 \\
\hline & B3 & 2.90 \\
\hline & $\mathrm{B} 4$ & 2.87 \\
\hline Set $C$ (control) & $\mathrm{C}$ & 5.23 \\
\hline
\end{tabular}

strength. Hence the drop in strength as percentage of starch increases was expected. The drop in strength could not be used as a criterion for making conclusions on viability of the composite batches. The strength requirements of intended applications, either load-bearing or non-load bearing, would be amore relevant deciding factor in selecting particular compositions for desired end use.

Furthermore, a less drastic fall in tensile strength values was noticed for sample set B containing CSS. Finer dispersed phase in a composite usually results in better strength and ability of the matrix to accommodate higher loadings of the additive. Hence this observation may be an indication that this starch type may be capable of forming smaller-sized particles.

\subsection{Biodegradability Test}

An analysis of the soil types was carried out to determine the $\mathrm{pH}$, soil composition and microbial content of each soil type were determined. This is presented in Table 3. The two soil samples are close to neutral with soil sample 2 tending to be slightly alkaline. Soil type 1 was clayey while soil type two was sandy. For soil type 1, Figure 3 show pictures of the sample surfaces for set A after burying for 28 days and prior to burying. In this soil type, sample set A exhibited an increased level of degradation as the proportion of starch was increased. This can be as seen by the relative extent of loss of surface material. This degradation is most severe in sample A4 with 20\% CNS.

For sample set $B$ in soil type 1, a remarkable departure from the degradation behaviour of set A can be seen in Figure 4. In this sample set, the specimen with the lowest proportion of starch, (sample B 1) degraded the most while those with the more proportions degraded less. This seemed initially counter-intuitive, but could be due to a number of factors including mixing of the polymer and corn starch, moulding into tensile specimen amongst other factors.

For Soil type 2, Figure 5 shows samples set $\mathrm{A}$ after burying for 28 days. The samples showed very little degradation. Figure 6 for sample set B showed evidence of only slight degradation as the CNS content was increased. 


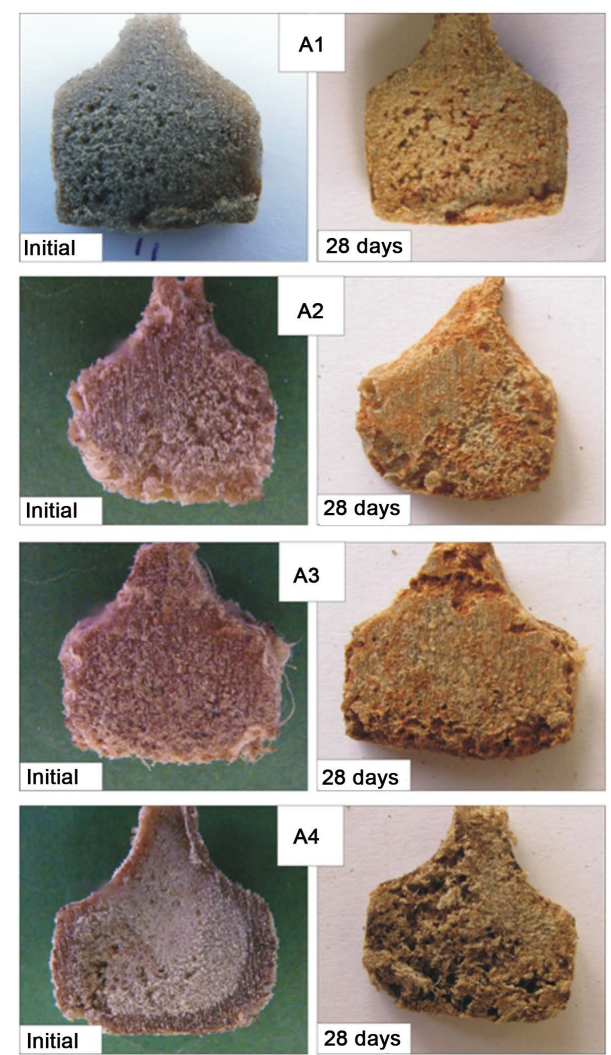

Figure 3. Degradation of samples of set A after 28 days in soil type 1 .
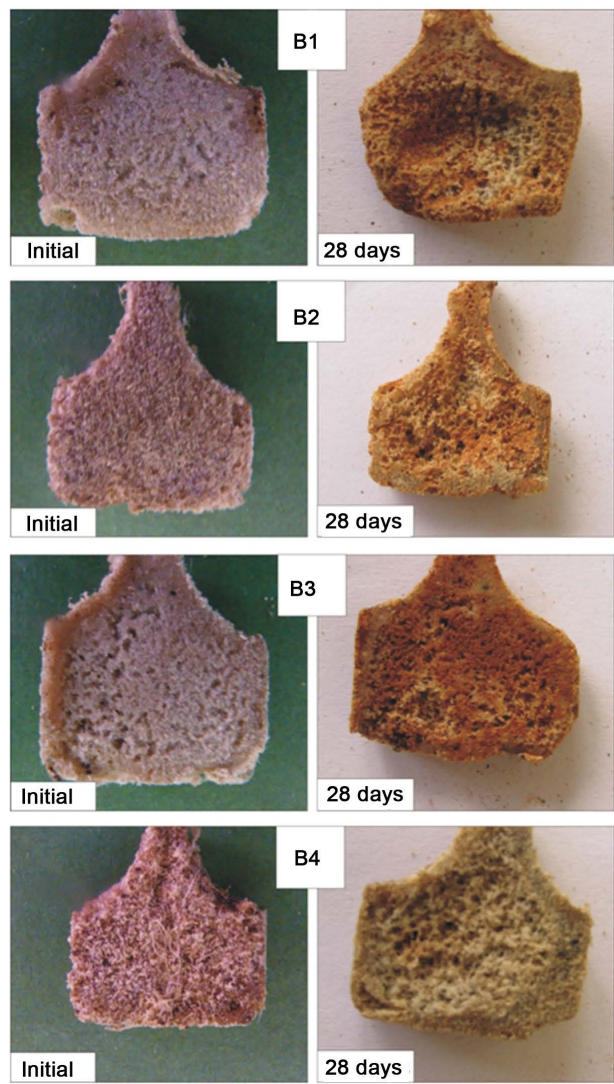

Figure 4. Degradation of sample set B after 28 days in soil type 1. 


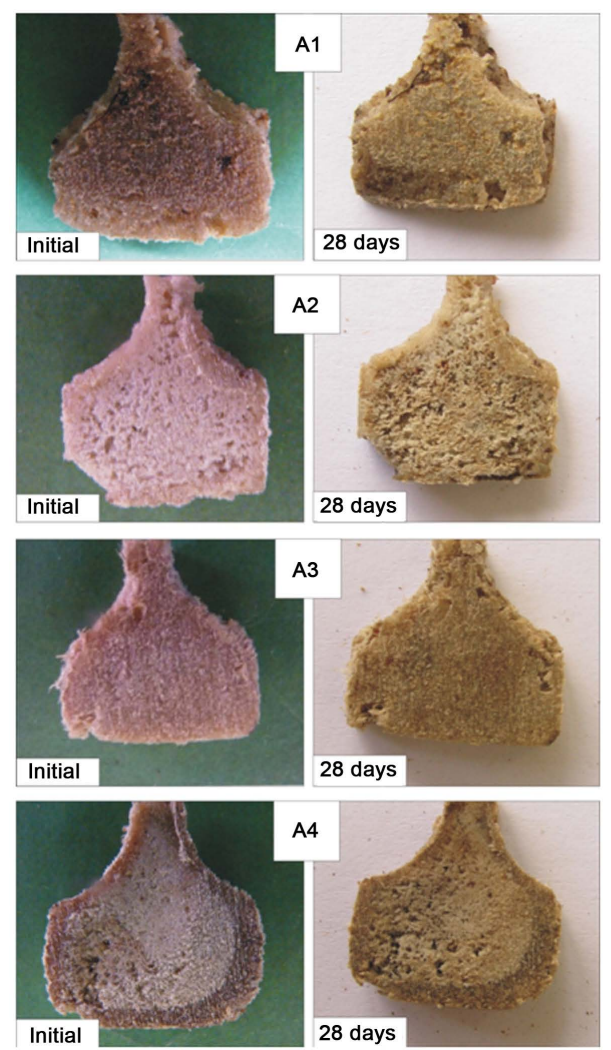

Figure 5. Degradation of sample set A after 28 days in soil type 2.
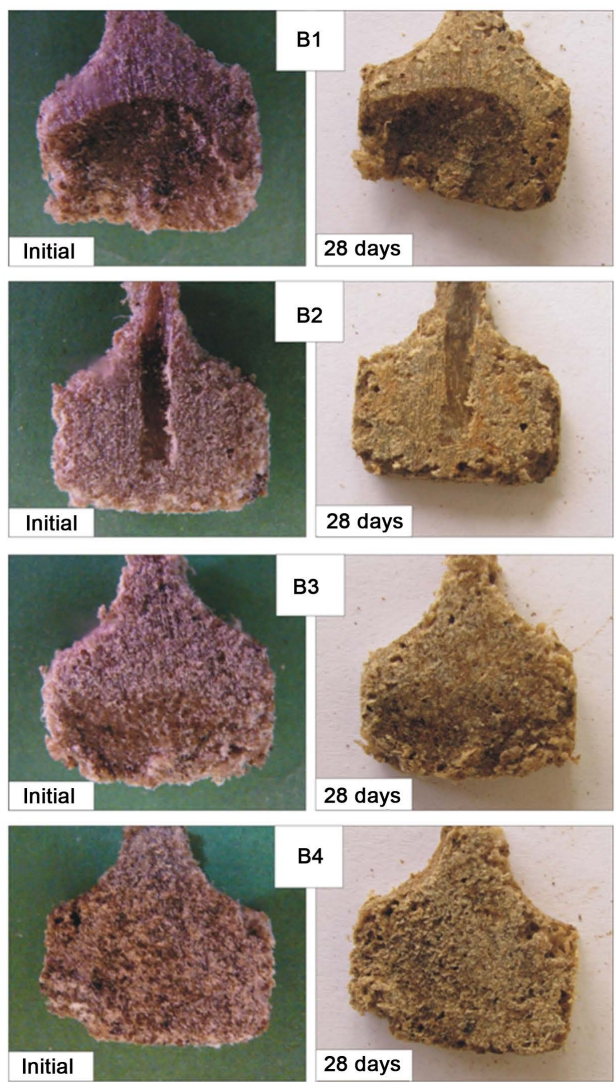

Figure 6. Degradation of sample set B after 28 days in soil type 2. 
Table 3. Analysis of soil types used in the biodegradability test.

\begin{tabular}{cccccccc}
\hline \multirow{2}{*}{$\begin{array}{c}\text { Soil } \\
\text { type }\end{array}$} & \multicolumn{2}{c}{$\mathrm{pH}$} & \multicolumn{3}{c}{ Soil composition } & \multicolumn{2}{c}{ Microbial content (cfu/gram) } \\
\cline { 2 - 7 } & $\mathrm{H}_{2} \mathrm{O}$ & $\mathrm{CaCl}_{2}$ & Sand (\%) & Silt (\%) & Clay (\%) & Bacteria & Fungi \\
\hline ST 1 & 7.0 & 6.8 & 42 & 14 & 44 & $6.0 \times 10^{7}$ & $1.5 \times 10^{5}$ \\
ST 2 & 8.3 & 7.0 & 68 & 14 & 18 & $3.3 \times 10^{7}$ & $5.0 \times 10^{4}$ \\
\hline
\end{tabular}

From the forgoing discussion, it could be inferred that both sample sets degraded better in soil type 1 . This increased level of degradation could be due to the fact that as shown in Table 2, the bacteria load of the soil type 1 was more than in soil sample 2. Hence, more active biological agents are available to carryon the degradation. Also, composites with CSS tend to degrade better than those with CNS. For instance in soil type 2, samples with CNS remained largely undegraded due to the soil's low bacteria agent load. This condition notwithstanding, degradation was still noticed in samples with CSS. In soil type 1, the most biologically active of the two soil types, the control sample, specimen $\mathrm{C}$ remained un-degraded as can be seen in Figure 7. The by-products of the degradation are fine polymer powders which are more easily naturally degraded due to their fine particle sizes.

Degradation occurs in plastics via different mechanisms. The mechanism of degradation may be by UV radiation (photo-degradation), heat (thermal degradation), ambient oxygen (oxidation) or a combination of several mechanisms. Conventional plastics such as PE are actually biodegradable. The problem is that the length, about 100 years, for this to be completely realised far exceeds that for normal organic materials. The presence of an organic additive such as starch however should promote biodegradation by indirectly influencing the more aggressive mechanisms of polymer degradation. Starch is an inexpensive and readily available natural polymer and can be processed into thermoplastic materials with the aid of plasticizers and under the action of heat and shear [16]. However this is a costly and energy-intensive process. Furthermore, poor water resistance and low strength significantly affect the use of such predominantly starch-derived polymers from mainstream use.

The presence of the starch-based PE composite in a biologically active medium, such a compost heap, would result in the preferential bio-degradation of the starch. The removal of the starch, an integral part of the matrix, weakens the composite and results in localised structural break-down. The ensuing loss of surface material further exposes underlying materials to degradative influences. Also, lost surface materials are expected to eventually facture into a powdery form. Degradation, being a chemical reaction should be expected to be increasingly aggressive in these smaller-sized particles. Even the otherwise slow rate of biodegradation should increase by several orders of aggressiveness.

\section{Conclusions}

As regards the result and analysis of this work, within the limit of experimental 

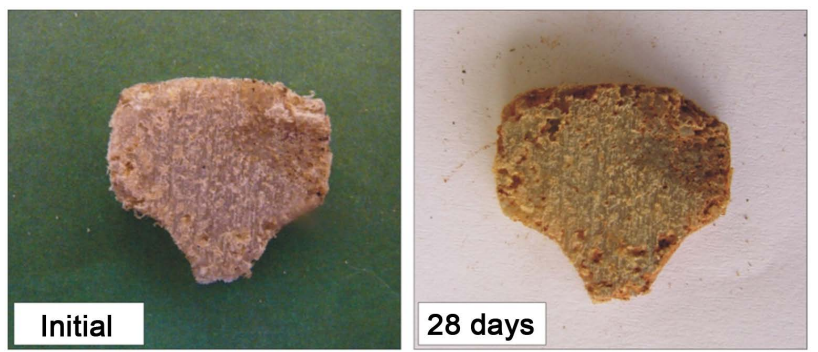

Figure 7. Control specimen $\mathrm{C}$ after 28 days in soil type 1.

errors, it can be concluded that both corn starch and cassava starch could impart biodegradability in polyethylene, with cassava starch being the better of the two. The soil type in which the polymer was buried also affects the biodegradability of the polymer. Soil types with high clay content, higher bacteria load and slightly alkaline tends to promote biodegradability.

The techniques and materials used in this work are easily adaptable to lowresource countries. The existing knowledge of polymer compounding in the $\mathrm{Ni}$ geria is well-suited to the actualisation of this novel approach of degradable PE for MSW mitigation.

\section{References}

[1] Centre for Sustainable Systems, University of Michigan (2010) Municipal Solid Waste Fact Sheet. Pub. No. CSS04-15.

[2] Ibimilua, A.F. and Ibimilua, F.O. (2015) Categorization, Characterisation, Management and Future Trends of Solid Wastes in Ado-Ekiti, Nigeria. Mediterranean Journal of Social Sciences, 6, 628-636.

[3] Sam, P.A. (2009) Are the Municipal Solid Waste Management Practices Causing Flooding during the Rainy Season in Accra, Ghana, West Africa. Research Findings, 24 June 2009.

http://www.modernghana.com/news/223779/1/are-the-municipal-solid-waste-man agement-practices.html

[4] Zake, J. (2008) Waste Management in Uganda; Issues for Policy and Practice Change. In: Waste Is Wealth Depending on How It Is Managed, Environmental Alert, Kampala, 1-12.

[5] Butu, A.W. and Mshelia, S.S. (2014) Municipal Solid Waste Disposal and Environmental Issues in Kano Metropolis, Nigeria. British Journal of Environmental Sciences, 2, 10-26.

[6] Staley, B.F. and Barlaz, M.A. (2009) Composition of Municipal Solid Waste in the United States and Implications for Carbon Sequestration and Methane Yield. Journal of Environmental Engineering, 135, 901-909. https://doi.org/10.1061/(ASCE)EE.1943-7870.0000032

[7] Carrington, R. (2007) Environmental Indicators and Selected Time Series. http://unstats.un.org/unsd/environment/Questionnaires/Website\%20tables\%20and \%20Selected\%20Time\%20Series/composition_municipal_waste_latestyear.pdf

[8] Gochfeld, M. (2011) Municipal Solid Waste. In: Gale Encyclopedia of Public Health. http://www.answers.com/topic/municipal-solid-waste

[9] U.S. Environmental Protection Agency (2009) Municipal Solid Waste Generation, Recycling, and Disposal in the United States: Facts and Figures 2008. 
[10] Gross, R.A. and Kalra, B. (2002) Biodegradable Polymers for the Environment. Science, 297, 803-806. https://doi.org/10.1126/science.297.5582.803

[11] Shivam, P. (2016) Recent Developments on Biodegradable Polymers and Their Future Trends. International Research Journal of Science and Engineering, 4, 17-26.

[12] Kolybaba, M., Tabil, L.G., Panigrahi, S., Crerar, W.J., Powel, T. and Wang, B. (2003) Biodegradable Polymers: Past, Present and Future. ASAE Paper Number: RRV030007, St. Joseph.

[13] Webster's Online Dictionary (2011) Extended Definition: Corn Starch. http://www.websters-online-dictionary.com/definitions/cornstarch

[14] Tonukari, N.J. (2004) Cassava and the Future of Starch. Electronic Journal of Biotechnology, 7, 5-8. https://doi.org/10.2225/vol7-issue1-fulltext-9

[15] Lacerda, G.L., Azevedo, J.A.M., Filho, M.A.S.C., Demiate, I.M., Schnitzler, E., Vandenberghe, L.P.S. and Soccol, C.R. (2008) Thermal Characterization of Partially Hydrolyzed Cassava (Manihot esculenta) Starch Granules. Brazilian Archives of Biology and Technology, 51, 1209-1216. https://doi.org/10.1590/S1516-89132008000600016

[16] Wang, X., Yang, K. and Wang, Y. (2004) Properties of Starch Blends with Biodegradable Polymers. Journal of Macromolecular Science Part C Polymer Reviews, 3 , 385-409.

Submit or recommend next manuscript to SCIRP and we will provide best service for you:

Accepting pre-submission inquiries through Email, Facebook, LinkedIn, Twitter, etc. A wide selection of journals (inclusive of 9 subjects, more than 200 journals) Providing 24-hour high-quality service User-friendly online submission system Fair and swift peer-review system Efficient typesetting and proofreading procedure Display of the result of downloads and visits, as well as the number of cited articles Maximum dissemination of your research work

Submit your manuscript at: http://papersubmission.scirp.org/ Or contact msa@scirp.org 